\title{
Patent pledge to Indian universities
}

\section{Critics worry that the push for technology transfer is moving too fast.}

India's parliament will soon be scrutinizing a bill intended to help publicly funded institutes and universities commercialize their research. India's science minister, Kapil Sibal, is confident that the bill will become law and will help Indian universities "make millions through patents".

But the bill has been pushed through without an open debate and is not publicly available, prompting concern. "In a democracy you cannot bulldoze a bill like this," says Pushpa Bhargava, former vice-chair of the National Knowledge Commission.

The idea is widely believed to be the brainchild of Raghunath Mashelkar, former director-general of the Council of Scientific and Industrial Research (CSIR), who has turned his own labs into veritable patent factories (see Nature 442, $120 ; 2006)$. After the knowledge commission backed the move in 2007, the government asked the Department of Biotechnology to draft wording for the bill, which the Indian cabinet approved on 31 October. It had been slated to go before a parliamentary committee this month, but the Mumbai terror attacks may cause it to be pushed into early 2009.

The bill is modelled on the 1980 US BayhDole Act, which allowed US universities to

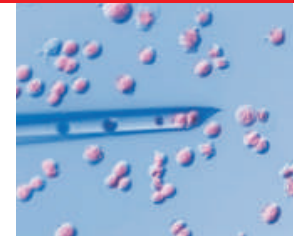

DUBIOUS DISPENSARIES

Stem cell society urges government to close bogus clinics

www.nature.com/news

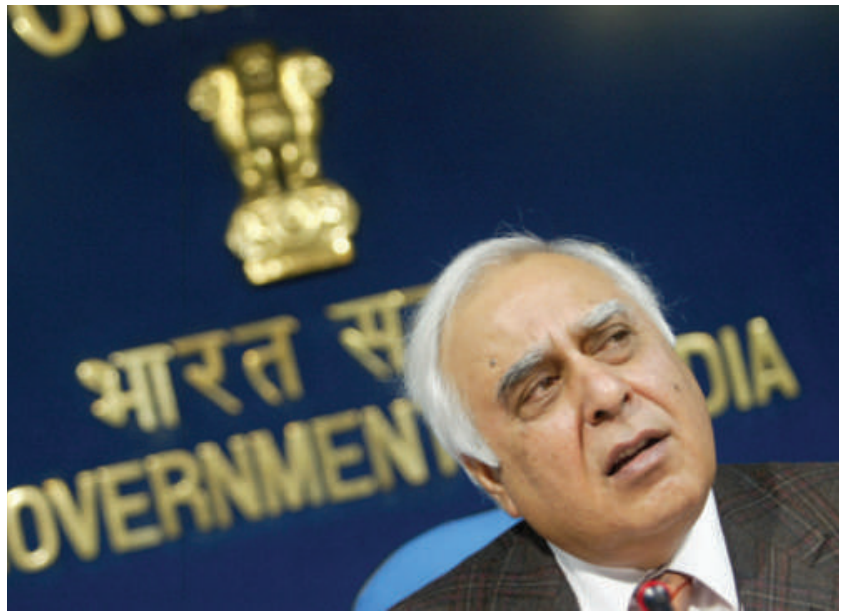

Kapil Sibal, India's science minister, wants the universities to create wealth.

the Federation of Indian Chambers of Commerce and Industry (FICCI) 章 in October. "We need to create an environment in which wealth can $\frac{\partial}{\Sigma}$ be generated from the university system."

Only a few top institutes in India have a good grasp of patents and markets. Between 1990 and 2002, Indian universities accounted for only $3 \%$ of patents filed by Indian organizations in the Indian patent office, and $1 \%$ of Indian patents filed in the US patent office, according to the New Delhi-based National Institute of Science, Technology and Development Studies. Researchers at institutes without a well-developed technology-transfer office can

patent discoveries derived from federally funded work. According to the Indian bill, scientists would be allowed to retain $30 \%$ of the net income earned from patents and licences. The scientist's institute would retain $40 \%$, with the rest going into a fund maintained by the institute for managing intellectual property. Researchers in publicly funded institutes or universities would also be allowed, for the first time, to set up and work in private companies without having to leave their academic jobs.

"The benefits of publicly funded research are not reaching the public," Sibal told a meeting of apply to the National Research Development Corporation in New Delhi for help in commercializing their work.

Heads of publicly funded institutes support the bill in principle. "This will empower universities in an era of patents and competitiveness," says Samir Brahmachari, director general of the CSIR. But he notes that scientists and institutes also need to strike a balance between earning profits and keeping the public interest in mind, especially in fields such as affordable health care and infectious diseases.

Most university academics have not read

\section{India creates funding council for basic science}

The Indian government plans to create an independent agency to promote basic research in science and engineering, along the lines of the US National Science Foundation, prime minister Manmohan Singh announced last week.

The new body, to be called the National Science and Engineering Research Board (NSERB), is expected to control an annual budget of 10 billion rupees (US $\$ 200$ million) annually - equivalent to about $15 \%$ of last year's total funding for science - in new funding. "It will provide unfettered financial assistance to researchers, academic institutions, research laboratories and industrial concerns," Singh told scientists on 3 December.

The idea of an autonomous funding agency was first mooted by the Department of Science and Technology (DST) in 2002. Prominent scientists including C. N. R. Rao, chairman of the prime minister's scientific advisory council, have been lobbying for it since. "I am happy that it has finally come through," says Rao.

Parliament will establish the NSERB during its session beginning this week, and the agency will be functional from the financial year beginning 1 April 2009, says DST secretary Thirumalachari Ramasamy. Its nine-member board will be chaired by an eminent scientist, to be named by the cabinet, and will have several advisory panels.

Scientists can currently get funding from departments such as health, agriculture, energy or biotechnology - but usually only for research related to these areas. The biggest source of funds for basic science is the DST's Science \& Engineering Research Council (SERC), which was set up in 1974. Last year, it distributed 3.6 billion rupees for projects in all disciplines.

Rao says that the current funding mechanisms are too bureaucratic. Ramasamy says that "the NSERB can be fast" as it is not subject to the same government rules as SERC. SERC would continue to function but only to provide money to improve university science laboratories and to handle scholarship and fellowship programmes.

The idea of an autonomous board is "wonderful", says Seyed Hasnain, vice-chancellor of the University of Hyderabad and a member of the prime minister's scientific advisory council. "My only concern is it should not end up as another agency funding scientists in institutions already having a big budget. The bulk of the board's funding must go to university researchers, who are most neglected now."

K. S. Jayaraman 
the bill, and their opinions on the initiative are mixed. Some welcome it, saying it will increase awareness of patenting. Others are concerned that teaching and basic research might get sidelined.

Indian industry is enthusiastic about the move. Amit Mitra, the FICCI's secretary general, argues that the Bayh-Dole Act helped US universities earn revenue from key discoveries, such as the anti-AIDS drug stavudine at Yale University and recombinant-DNA technology at the University of California and Stanford University.

But some analysts say that the US model cannot be replicated in India, where most universities are hampered by poor funds and outdated infrastructure, and where fewer students are choosing to take up science. "Many students end up doing neither frontline basic science nor applied technology, and fall in-between with mediocre work," notes Ashok Parthasarathi, former science adviser to the Indian government. He says the bill is both "impractical and
PATENT RATES: INDIA VS CHINA

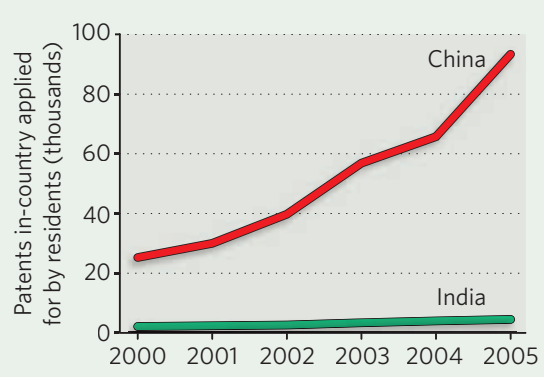

infeasible" to implement, specifying what he calls "absurd time periods". The university or laboratory in question would need to notify the government about patentable results within 60 days of realizing the patent potential, and indicate within 90 days the countries it would file patent in.

"One should not expect Indian universities to have an instant capacity to file and maintain patents, follow up on infringements, and negotiate technology transfers," adds Krishna
Ravi Srinivas, an associate fellow at the New Delhi-based Research and Information System for Developing Countries. Still, he says, "a beginning has to be made somewhere, and Bayh-Dole is the best model we have".

Within the past few years, China, Brazil, Malaysia and South Africa have passed Bayh-Dole-type laws, hoping to capitalize on their research. But some experts argue that this approach may not work in developing countries.

Bhaven Sampat, an economist at Columbia University in New York City and co-author of a recent study on the subject (A. D. So et al. PLoS Biol. 6, e262; 2008), argues that Bayh-Dole did not significantly affect the commercialization of US academic research. He cites 2006 data from the Association of University Technology Managers that suggest US universities, hospitals and research institutions derived \$1.85 billion from technology licensing - less than $5 \%$ of the money they received from federal, state and industry funders.

T. V. Padma

\section{UN suspends leading carbon-offset firm}

As international climate talks began last week in Poland, the United Nations (UN) suspended the work of the main company that validates carbon-offset projects in developing countries, sending shockwaves through the emissionstrading business.

Based in Oslo, Det Norske Veritas has in the past four years validated and certified almost half of the 1,200 projects approved under the 1997 Kyoto Protocol's Clean Development Mechanism (CDM). At its meeting on 28 November in Poznań, the CDM's executive board temporarily withdrew Det Norske Veritas's accreditation after a spot check carried out in early November at the firm's headquarters revealed serious flaws in project management.

The board did not specify which projects are affected, but cites problems with the company's internal auditing processes, and says that one of its staff members was verifying CDM projects without proper qualifications. As a result, "validation activities could not be demonstrated to be based on appropriate sectoral expertise", the board reports.

Det Norske Veritas is a risk-assessment and consulting company with about 8,000 employees in more than 100 countries. Its 2007 revenue was 8 billion Norwegian krone (US $\$ 1.1$ billion).

Environmental groups have criticized the social impact of the Xiaoxi hydropower station.
It was the largest of 19 companies entitled to validate and certify projects proposed under the CDM, which aims to cut greenhouse-gas emissions by promoting climate-friendly energy technologies, such as wind or hydropower.

Certified emission-reduction credits from verified projects can be traded and sold on the emissions market, helping industrialized countries to meet their emissions-reduction targets under the Kyoto Protocol. However, only environmentally sustainable projects that would demonstrably not go ahead without additional revenue from sales of these credits are meant to be approved.

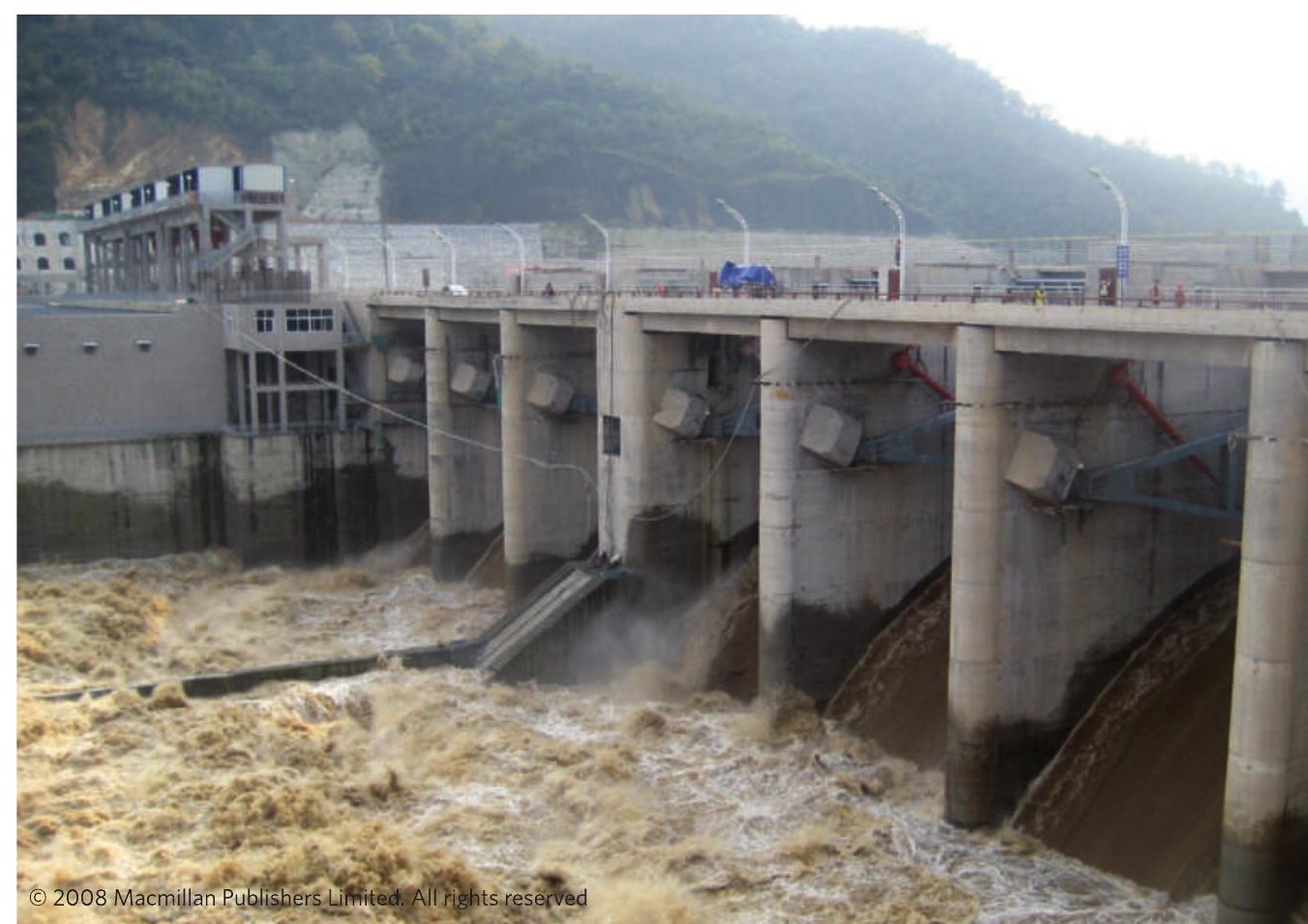

